logos_i_ethos_2020_1_(53), s. 119-140

DOI: http://dx.doi.org/10.15633/lie.3692

Milena Cygan

https://orcid.org/0000-0003-1407-7183

Uniwersytet Papieski Jana Pawła II w Krakowie

\title{
Prepozytywistyczna (?) koncepcja filozofii narodowej Michała Wiszniewskiego
}

\section{Cz. 1: Źródła i inspiracje}

Michał Wiszniewski, profesor Uniwersytetu Jagiellońskiego, filozof, historyki kilkugodzinny dyktator powstania krakowskiego, uczony którego złożone koleje życia zaprowadziły ze świata naukowego na wygnanie, emigrację i skazały na zapomnienie. Uchodził w pierwszej połowie XIX wieku za jednego

Milena Cygan - mgr, doktorantka w Katedrze Historii i Filozofii Nauki Uniwersytetu Papieskiego Jana Pawła II w Krakowie. Absolwentka studiów magisterskich na Wydziałach Teologicznym i Filozoficznym UPJPII. Zainteresowania naukowe: historia filozofii i nauki polskiej, antropologia, relacje pomiędzy filozofią i religią, nauki ewolucyjne, etologia. z bardziej znanych i rozpoznawanych polskich myślicieli. Swoją działalność naukową rozwijał zwłaszcza w tym okresie, gdy polskie umysły zdominowała idealistyczna filozofia niemiecka. Tworzone były wówczas wielkie systemy metafizyczne, jak na przykład ten zaproponowany przez Hegla, które na polski grunt przeszczepiali filozofowie, myśliciele i literaci zwani romantykami. To właśnie oni „podporządkowali” sobie ówczesną scenę filozoficzną, tak, że wydawać by się mogło, iż w świecie intelektualnym i filozoficznym nic więcej się nie działo. Duchowe odrodzenie Polaków, podnoszenie idei narodowych, słowianofilstwo i ludomania - cechy charakterystyczne romantyków, okazują się być 
jednak wspólnym dziedzictwem myślicieli tamtych czasów, obejmując swoim oddziaływaniem także grupę nieromantycznie zorientowanych filozofów. Reprezentował je między innymi właśnie Michał Wiszniewski, który na pewno do romantyków nie należał. Jako spadkobierca ideałów oświeceniowych, hołdujący szkockiej filozofii „zdrowego rozsądku”, filozofię typu idealistycznego i romantycznego uważał za zbyt abstrakcyjną, marzycielską, oderwaną od konkretnej rzeczywistości, którą trzeba przemieniać „tu i teraz” poprzez pracę i wysiłek, odpowiadający rzeczywistym możliwościom, jakie niesie ze sobą konkretny moment historyczny.

Niemniej, Wiszniewski zdaje się nie być również myślicielem oświeceniowym, choć oczywiście z epoką tą miał jeszcze wiele wspólnego ${ }^{1}$. W opracowaniach z zakresu historii filozofii zazwyczaj bywa wspominany jako prepozytywista, czyli filozof należący do nurtu prekursorskiego w stosunku do pozytywizmu, który to nurt operował tylko częściowym zespołem tez pozytywistycznych. Jak zaznacza Barbara Skarga, zespół ten mógł występować $\mathrm{u}$ różnych myślicieli $\mathrm{w}$ formie mało skrystalizowanej, uwikłany w obcą sobie konstrukcję myślową. Nie mogło to być jednak byle jakie uwikłanie. O prepozytywizmie można bowiem mówić tylko wtedy, gdy ów zespół cech funkcjonował tak, iż wywierał wpływ na owe konstrukcje, przekształcał je w nowym duchu, uwidaczniając odmienność postaw teoretycznych i moralno-politycznych, do których prowadził. Chociaż więc obecność prepozytywistycznych wątków można stwierdzić u większości romantyków (np. u Cieszkowskiego czy Libelta), to jednak z pewnością nie byli oni prepozytywistami ${ }^{2}$. I na odwrót, u niektórych prepozytywistów można rozpoznać idee romantyczne, choć nie byli oni romantykami. Tak właśnie stało się w przypadku Wiszniewskiego. Mimo ogólnie antyromantycznego usposobienia,

1 Zdaniem Jana Wępsięcia filozofia Wiszniewskiego była ostatnim etapem empiryzmu oświecenia i pomostem łączącym go z pozytywizmem. Zob. J. Wepsięć, Michał Wiszniewski i jego filozofia na tle empiryzmu z epoki polskiego Oświecenia, „Kwartalnik Filozoficzny” 15 (1938) z. 3, s. 277. Natomiast Barbara Skarga uważała, że należał on do tych myślicieli, którzy nie kontynuowali idei oświeceniowych, lecz raczej dokonywali od nich dalszego odwrotu. Zob. B. Skarga, Narodziny pozytywizmu polskiego 1831-1864, Warszawa 2013, s. 60.

2 Por. B. Skarga, Narodziny pozytywizmu polskiego..., dz. cyt., s. 46. 
podobnie jak oni głosił idee powrotu do zapoznanej polskości, postulował odrodzenie kultury polskiej, konieczność stworzenia filozofii rodzimej - zgodnej z charakterem umysłowości i duchowości narodowej, nadbudowanej na zapomnianym i niedowartościowanym dziedzictwie Słowian. Jednakże, w związku z tym, że jego filozoficzne postulaty opierały się na nieco innych założeniach niż wspomnianych idealistów, jego koncepcja filozofii narodowej odznaczała się specyficznym charakterem, który - ze względu na ogół poglądów wyznawanych przez tegoż autora wydawać by się mogło, że można by nazwać właśnie prepozytywistycznym. Niemniej także to określenie, $z$ uwagi na częste występowanie w tej koncepcji idei, które dzielił wraz z „potępianymi” przez siebie romantykami, jawi się jako nieadekwatne. Przez wzgląd na to, iż prepozytywista, którym był Wiszniewski, w swojej koncepcji filozofii narodowej wydaje się być bliższy romantykom, nazwanie jej „prepozytywistyczną” nie jest tu jednoznacznym zakwalifikowaniem, lecz raczej przeradza się w niniejszym artykule w pytanie, o to „czy?” i „na ile?” ten nieromantyczny projekt filozofii rodzimej jest faktycznie prepozytywistyczny.

W literaturze historyczno-filozoficznej rzadko wspomina się nie tylko samego Wiszniewskiego, lecz także jego ideę filozofii narodowej, choć to on, jako jeden z pierwszych - na co wskazywał Gabriel Korbut jeszcze przed Maurycym Mochnackim, wprost wzywał rodaków do jej stworzenia ${ }^{3}$. Wstępne badania w tym zakresie przeprowadził dotychczas Józef Bańka w swojej monografii poświęconej Wiszniewskiemu. Dlatego też celem tego artykułu (zarówno jego części pierwszej, jak i drugiej) jest rekonstrukcja i analiza idei filozofii narodowej, jaką prezentował Wiszniewski w swoich opublikowanych pismach ${ }^{4}$. Nie napisał on osobnego dzieła dedykowanego w całości temu zagadnieniu, jednakże myśli odnoszące się do koncepcji filozofii narodowej znajdują się w różnych jego pracach. Celem artykułu jest więc ich wydobycie, uporządkowanie i dostarczenie w miarę całościowego i spójnego obrazu tejże koncepcji. Aby uzyskać zamierzony efekt, wskazując jednocześnie nie tylko

3 Zob. G. Korbut, Michał Wiszniewski i spuścizna po nim, Warszawa 1901, s. 11.

$4 \mathrm{~W}$ artykule nie zostały uwzględnione prace, notatki i listy pozostające dotychczas w rękopisach. 
na wspólne cechy, które Wiszniewski dzielił z przedstawicielami epoki, lecz także to, co tę jego koncepcję wyróżniało, pokazując, że filozofia narodowa niekoniecznie musi oznaczać to samo, co filozofia romantyczna o tendencjach mesjanistycznych, artykuł został podzielony na dwie części. W pierwszej omówione zostaną źródła koncepcji filozofii narodowej Wiszniewskiego, czyli tło historyczne, na którym rodziła się idea filozofii narodowej w ogóle, oraz inspiracje, które skłoniły go do sformułowania postulatu potrzeby stworzenia filozofii narodowej. W części drugiej natomiast zostaną zaprezentowane i poddane analizie poglądy Wiszniewskiego na temat charakteru polskiej filozofii narodowej i języka, w jakim ma się ona wyrażać. Pominięta została jednak ewentualna recepcja myśli Wiszniewskiego, jej oddziaływanie na innych myślicieli, gdyż to już temat na osobną pracę.

\section{Idea filozofii narodowej - kontekst historyczno-filozoficzny}

Rozwój idei filozofii narodowej zwykle umiejscawia się w XIX wieku. Jednakże już na wstępie warto zauważyć, że w tym wieku można raczej mówić o jej „rozkwicie” w pełnym słowa tego znaczeniu, niż o jej powstaniu jako takim, ponieważ owa idea swymi korzeniami sięga nieco dalej w przeszłość. Niektórzy uczeni, jak na przykład Stanisław Garfein-Garski, jej początku upatrują już w samym przejściu od średniowiecza do czasów nowożytnych, czego najbardziej transparentnym znakiem było zastąpienie w literaturze języka łacińskiego językiem narodowym ${ }^{5}$. Niemniej jednak idea narodowa bardziej okazale zaczęła się uwydatniać dopiero w połowie XVIII wieku. Do tego bowiem czasu filozofia w Europie miała raczej charakter uniwersalny, kosmopolityczny. Wskazuje na to między innymi Henryk Struve, pisząc, że „Jeszcze za czasów Bacona, Kartezjusza, Spinozy i nawet Leibniza rozwój filozofii, pomimo całej różnorodności w swych czynnikach zasadniczych, podobny był do rzeki, płynącej jednym szerokim korytem, unosząc na swych falach

5 Zob. S. Garfein-Garski, Zagadnienie polskiej filozofii narodowej, w: Polska filozofia narodowa, red. M. Straszewski, Kraków 1921, s. 5. 
wszystkie bogactwa myśli europejskiej [...]. Z chwilą atoli, gdy nauka poczęła mówić językiem narodowym, to wszystko uległo zmianie bardzo poważnej. Jedna wspaniała rzeka myśli rozdzieliła się na wielką liczbę samodzielnych ramion, z których żadne nie mogło się szczycić, że jednoczy w sobie wszystkie dążności ducha ludzkiego, że jest jedynym lub głównym wyrazem tych dążności. W miejsce jednej ogólnej, uniwersalnej filozofii, powstała filozofii angielska, francuska, niemiecka i inne, z których każda przedstawiała nie całą filozofię, lecz jeden tylko prąd myśli filozoficznej”'.

Filozofia uniwersalna powoli zaczęła więc ustępować miejsca filozofii narodowej. Tym czynnikiem decydującym miał być według Struvego język używany w naukowym dyskursie. Jednakże równocześnie ze wzrostem zainteresowania używaniem własnego języka rozwijała się także świadomość tożsamości narodowej. Wraz tym budziła się pewna refleksja nad narodem - budziła się idea narodowa. Jak zaznacza Garfein-Garski, można o niej mówić już wtedy, gdy Monteskiusz snuł refleksje nad stosunkiem ustaw do ducha narodu; Wolter pisał o obyczajach narodu i jego duchu oraz wówczas, kiedy w ogóle zaczynały się szerzyć we Francji przeszczepione z Anglii idee swobody. Nie można także w tym kontekście nie wspomnieć o dziełach Rousseau, jako źródle interesujących nas zagadnień. Jednakże zdaniem tego uczonego ta idea narodowa uzewnętrzniła się najbardziej w ruchu emancypacyjnym trzeciego stanu, co najgwałtowniej przejawiło się rewolucji francuskiej. Zebranie narodowe, odrzuciwszy postawioną przez Mirabeau propozycję określenia się jako przedstawicielstwa ludu francuskiego, obrało nazwę Zgromadzenia Narodowego. Ponadto do Deklaracji praw człowieka został zaproponowany dodatek o wszechwładztwie oddzielnych narodów, wykluczający ingerencje jednego narodu w sprawy drugiego. Z głoszonej więc przez rewolucję francuską idei demokratyzacji, wraz z zasadami wolności i równości każdej jednostki, wypływały konsekwentnie

6 H. Struve, Historia filozofii w Polsce na tle ogólnego rozwoju życia umysłowego, Warszawa 1900, s. 40 . 
takie same zasady dla narodów, co oznaczało, że i one są oddzielnymi jednostkami, tylko wyższego rzędu ${ }^{7}$.

Warto jednak zauważyć, że ta oświeceniowa koncepcja narodu, wywodząca się z ducha rewolucji francuskiej oraz $\mathrm{z}$ idei samostanowienia o sobie, suwerenności ludu i z dążenia do politycznej podmiotowości była koncepcją narodu „polityczną”. Naród w tym ujęciu to „naród polityczny”, dzielący wspólną historię państwa i porządek prawny. Niemniej jednak, nie to ujęcie wpłynęło na rozwój idei filozofii narodowej. Oddziałała tu raczej koncepcja „kulturowa” narodu, ukazująca go jako wspólnotę złączoną językiem, dziedzictwem kulturowym, jednym słowem mówiąc: tradycją. Ta druga koncepcja - jak podkreśla Andrzej Walicki - dążąca do wyrażenia i umocnienia zbiorowej indywidualności narodu, wywodziła się z protestu przeciw uniwersalizmowi oświecenia, a jej najdoskonalszym „modelowym” wcieleniem okazał się niemiecki romantyzm. Siłę tego „kulturowego nacjonalizmu” stanowiło docenienie i podkreślenie irracjonalnych składników więzi narodowych, słabość natomiast - brak potrzeby unifikacji politycznej i prawnej, a także absolutnej suwerenności państwa. Inaczej rzecz ujmując: naród w tym paradygmacie nie potrzebuje państwa - tym, co go definiuje, jest przede wszystkim język i kultura. To właśnie ta koncepcja silnie wpłynęła na dziewiętnastowiecznych Polaków, pozbawionych swojego państwa. Jedyne, co im wówczas zostało, to „duch narodowy”, którego istnienie zaczęto sobie uświadamiać jak nigdy przedtem ${ }^{8}$.

Chociaż więc idea narodu kulturowego zadomowiła się w wieku XIX, szczególnie eksploatowana przez romantyków, to jednak jej źródeł również trzeba szukać wcześniej, mianowicie u oświeceniowych prekursorów tego ruchu. Jak powszechnie wiadomo, zaplecze teoretyczne pod rozwój romantycznej idei przygotował Johann Gottfried Herder, który w opozycji do oświeceniowych koncepcji historiozoficznych przyjął, że istota realnego człowieczeństwa nie leży w globalnej kulturze, lecz w każdym

7 Por. S. Garfein-Garski, Zagadnienie polskiej filozofii narodowej, dz. cyt., s. 5-6.

8 Por. A. Walicki, Idea narodu w polskiej myśli oświeceniowej, „Archiwum Historii Filozofii i Myśli Społecznej” 26 (1980), s. 36. 
narodzie z osobna, posiadającym wartość samą w sobie. Podążając za Herderem, romantyzm odrzucił przekonanie, że droga do człowieczeństwa prowadzi poprzez unifikację kulturową narodów. Uniformizm, typowa cecha uniwersalizmu oświeceniowego, ustąpił zatem miejsca przekonaniu, podkreślającemu różnorodność kultur narodowych jako niepowtarzalnych i jedynych indywiduacji człowieczeństwa ${ }^{9}$. Główne idee Herderowskiej filozofii sprowadzały się do konstatacji, że każdy naród posiada własną kulturę, specyficzny sposób istnienia, odczuwania i przeżywania. Jednym z najważniejszych spoiw narodu jest - jego zdaniem - język, „w którym ukrywa się dusza narodu wraz z wszystkimi cechami ją indywidualizującymi. W duszy narodu ukrywa się z kolei cała mądrość narodu, jego filozofia i zdolność do konkretnego wyrażania pojęć; w języku odbija się intelekt i charakter danego narodu”10. „Duszę narodu", którą była dla niego wspólnota nie tylko pokoleń teraźniejszych, lecz także przeszłych i przyszłych, konstytuowały kultura i język, czyli, jakbyśmy dzisiaj powiedzieli, wspólna tradycja. Ponadto zasługą Herdera jest zaszczepienie słowianofilstwa, co z wiadomych przyczyn zyskało znaczną popularność w krajach słowiańskich. Zwłaszcza zamieszczone w Myślach o filozofii dziejów przepowiednie co do przyszłych losów Słowian, którym Herder zapowiada mesjanistyczne posłannictwo krzewienia człowieczeństwa ${ }^{11}$, zyskały tam dużą popularność.

Idee te, zwłaszcza słowianofilstwo, jak sygnalizowano wcześniej, znajdą szeroki oddźwięk i podatny grunt do rozwoju także w Polsce. Wielu uczonych zaczęło wówczas podkreślać wartość języka polskiego, narodowego i konieczność tworzenia literatury i filozofii narodowej ${ }^{12}$. Szukając dalszego uzasadnienia dla tworzonych programów filozofii narodowej, powoływano się na idealistów niemieckich, zwłaszcza na Hegla. Jego pogląd, iż każda filozofia jest nie tylko filozofią danego czasu,

9 Por. R. Wiśniewski, Karola Libelta „system umnictwa” jako filozofia narodowa, „Szkice Humanistyczne" 10 (2010) nr 1, s. 64.

10 J. G. Herder, Myśli o filozofii dziejów, t. 1, tłum. J. Gałecki, Warszawa 1962, s. 404.

11 Zob. J. G. Herder, Myśli o filozofii dziejów, t. 2, tłum. J. Gałecki, Warszawa 1962, s. 326-328.

12 Por. P. Szymaniec, Pojęcie narodu w filozofii dziejów Johanna Gottfrieda Herdera, „Wrocławskie Studia Erazmiańskie" 1 (2008), s. 34. 
lecz ekspresją ducha danego narodu, okazał się kolejnym inspirującym czynnikiem. Z tezy, że każda filozofia przedstawia określony szczebel w ewolucji idei i że owa idea może się rozwijać jedynie poprzez narody, ówcześni myśliciele wysnuli wniosek, że filozofia musi być filozofią narodową. Każda filozofia jest bowiem koniecznym szczeblem w rozwoju prawdy, dokonującym się w czasie. Wobec tego ówcześni myśliciele doszli do przekonania, że w ich czasach nadeszła kolej na przebudzenie się narodów słowiańskich, szczególnie na naród polski, który przejmie obowiązek przewodzenia historii ${ }^{13}$. Myśl Herdera, Hegla, a także Schellinga, Fichtego stała się ważną inspiracją dla polskich filozofów, zwłaszcza o orientacji romantycznej, mesjanistycznej. Tak silna recepcja owej idei nie powinna dziwić, bo jak się okaże poniżej, Polacy mieli już wcześniej zaszczepione stosunkowo wysokie mniemanie o swoim dziejowym posłannictwie.

W obrębie myśli polskiej kwestia filozofii rodzimej pojawiła się genetycznie rzecz biorąc później, niż problem filozofii narodu. Ta, jako refleksja o narodzie, jego funkcjach i celach, sięga u nas w głąb czasów sarmackich i oświecenia. Struve w swojej Historii filozofii w Polsce wspomina, że już w XVIII wieku byli u nas autorzy przypisujący bądź to słowiańszczyźnie, bądź narodowi polskiemu wyjątkowe stanowisko w dziejach. Wspomina tu Jana Dębińskiego, który twierdził, że Bóg wyznaczył Polsce ważną funkcję wśród narodów, biorąc ją pod swoją szczególną opiekę, która, choć czasem pozwala nam „upadać”, to jednak nie pozwala nigdy zupełnie zginąć; dalej Szymona Majchrowicza i jego dzieło Trwałość szczęśliwa królestw albo ich smutny upadek, w którym dowodzi, że Polacy powołani są do obrony wiary, walki z kacerstwem, a tym samym bronienia innych narodów przed innowiercami i herezjami; Franciszka Jezierskiego, który określa Polaków jako ludzi pełnych świętej prostoty i niewinności życia ${ }^{14}$. „Zarówno Kołłątaj - pisze Struve - i Wawrzyniec Surowiecki, jak Lelewel, Adam Czarnocki, Wacław Maciejowski i inni

13 Por. R. Kozłowski, Koncepcja „, filozofii narodowej” Liberta i Trentowskiego, „Archiwum Historii Filozofii i Myśli Społecznej” 16 (1970), s. 37.

14 Zob. H. Struve, Historia filozofii $w$ Polsce..., dz. cyt., s. 46-48. 
mówili w swych pracach historiozoficznych o wyższości to narodu polskiego, to w ogóle ludów słowiańskich nad innymi, mianowicie co do wolności i poczucia braterstwa, i powoływali się w tym względzie już na świadectwo starych kronikarzy"15. Idea wyjątkowego posłannictwa narodu polskiego nie była więc nowa i rozwijała się w różnych kierunkach, wzbogacona recepcją filozofii niemieckiej, osiągnęła swoje apogeum w pierwszej połowie XIX wieku, zwłaszcza w myśli takich uczonych jak, Józef Hoene-Wroński, August Cieszkowski, Bronisław Trentowski czy Karol Libelt.

Chociaż idea mesjanistyczna zdominowała znacząco filozofię narodową, w jakiś sposób ją określając, to jednak nie wszyscy myśliciele byli mesjanistami, a sama filozofia narodowa miała w pierwszej kolejności nie tyle służyć „światu”, co narodowi, czyli Polakom. Jej kreowanie wynikało więc przede wszystkim z potrzeb samych Polaków. Zaważyła na tym zdecydowanie sytuacja społeczno-polityczna Polski w XVIII i XIX wieku związana z utratą bytu państwowego. Fakt ten wyzwolił ową potrzebę i to ona w dużej mierze determinowała charakter celów, jakie miała realizować filozofia narodowa. Celem tym było budzenie w Polakach ufności w potęgę i siłę narodu oraz własne duchowe i twórcze możliwości. Filozofia narodowa miała pełnić misję historyczną, kulturową, wychowawczą. Jednym z pierwszych jej orędowników był Józef Kalasanty Szaniawski, w którym Wiszniewski rozczytywał się za swoich lat szkolnych ${ }^{16}$. Nawoływał on do zapoznawania się z filozofiami niemieckimi (filozofią Kanta, Schellinga), najlepiej, w jego opinii, przyczyniającymi się do rozwijania w narodzie jego „samodzielności umysłowej”, tj. krytycyzmu, koniecznego do określenia własnej tożsamości narodowej ${ }^{17}$. Podobnie wypowiadał się Jan Śniadecki - intelektualny mentor naszego filozofa - w jednym ze swoich listów, gdy podkreślał, że w niczym nie powinniśmy naśladować Niemców, jak tylko w wytrwałości i pracy, żeby móc osiągnąć

15 H. Struve, Historia filozofii w Polsce..., dz. cyt., s. 47.

16 Zob. M. Wiszniewski, Myśli o ukształceniu samego siebie, Warszawa 1873, s. 107.

17 Zob. J. K. Szaniawski, Rady przyjacielskie młodemu czcicielowi nauk i filozofii, pragnacemu znaleźć pewniejszą drogę do prawdziwego i wyższego oświecenia, Warszawa 1805, s. 15-16. 
coś na polu własnej nauki i filozofii ${ }^{18}$. O tym, że każdy naród, w tym także polski, powinien mieć swoją filozofię mówił Józef Gołuchowski ${ }^{19}$. Za ideą stworzenia filozofii dla Polaków opowiadał się także Feliks Jaroń$\mathrm{ski}^{20}$. Do zerwania z obcymi filozofiami i porzucenia ślepego naśladownictwa obcych wzorów i idei wzywał Kazimierz Brodziński. O potrzebie filozofii ściśle złączonej z narodowością i samodzielności w myśleniu pisał Mochnacki ${ }^{21}$. W podobnym duchu, jak dowodzi Stefan Haras$\mathrm{sek}^{22}$, wypowiadali się także Józef Franciszek Królikowski, Wincenty Pol, Bronisław Trentowski, Karol Libelt. Analogiczne poglądy rozwijały się jednocześnie z przekonaniem, iż „duch narodu” jest całością indywidualną wyższego rzędu i że charakter narodu polskiego, i w ogóle ludu słowiańskiego, ma zupełnie swoiste i odrębne od innych cechy. Twierdzili tak, między innymi, wspomniany Szaniawski, Brodziński, Ostrowski, a także Józef Bychowiec, Józef Łętowski, Edward Dembowski, Antoni Małecki, Jan Rymarkiewicz. Myśliciele, nawołujący do stworzenia filozofii narodowej, oryginalnej, zgodnej z duchem narodu, posługiwali się jeszcze jednym argumentem, a mianowicie uważali, że język polski jest „filozoficzny” i że nadaje się znakomicie do budowania filozofii narodowej. Pod wpływem wspomnianego Herdera, myśliciele jak na przykład: Jan Samuel Kaulfuss, Franciszek Jezierski, Libelt, Jan Nepomucen Kamiński, Henryk Rzewuski, Feliks Kozłowski, Walenty Chłędowski, Kaziemierz Bujnicki, dowodzili, że język jest wyrazem charakteru narodowego ${ }^{23}$. Tym sposobem zrodziło się więc przekonanie o ścisłym związku pomiędzy językiem danego narodu i jego filozofią, przeświadczenie o filozoficzności polszczyzny, a nawet jej wyższości nad innymi językami w tworzeniu filozoficznych pojęć. Do tych wszystkich idei, nie

18 Por. I. Halpern, Jan Śniadecki, w: Polska filozofia narodowa, dz. cyt., s. 44.

19 Por. A. Walicki, Zarys dziejów filozofii polskiej (1815-1918), Warszawa 1986, s. 18.

20 Zob. F. Jaroński, Jakiej filozofii Polacy potrzebuja, w: Jakiej filozofii Polacy potrzebuja, red. W. Tatarkiewicz, Warszawa 1970, s. 4.

${ }^{21}$ Por. J. Skoczyński, J. Woleński, Historia filozofii polskiej, Kraków 2010, s. 251-252.

22 Zob. S. Harassek, Prolegomena do filozofii narodowej Trentowskiego, „Kwartalnik Filozoficzny” 11 (1933), s. 301-331.

23 Por. S. Harassek, Prolegomena do filozofii narodowej Trentowskiego, dz. cyt., s. 301-331. 
będąc romantykiem i mesjanistą, odwoływał się także Wiszniewski. Jak więc widać, jego koncepcja wpisuje się ogólny trend ideowy tamtych czasów. Jednakże nieco inne rozłożenie filozoficznych akcentów nadaje tej koncepcji swoisty charakter.

\section{Potrzeba filozofii rodzimej}

Idea filozofii narodowej na ziemiach polskich, jak pokazano powyżej, rozwijała się w czasie, kiedy z dziejowego punktu widzenia mogłoby się zdawać, że Polacy jako naród ginęli. Utrata niepodległości, czasy porozbiorowe, gdy zaborcy dokładali wszelkich starań, by pozbawionych bytu państwowego Polaków pozbawić także bytu kulturowego - wszystkie te okoliczności powinny były sprawić, że naród polski ulegnie i zatraci się w obcym środowisku. A jednak działo się dokładnie odwrotnie. To właśnie wtedy z całą mocą uświadomiono sobie, że to, co pozwoli narodowi przetrwać i nie utracić swojej tożsamości, tkwi w pielęgnowaniu i powrocie do rodzimych tradycji i oparciu się na tym, co najbardziej polskie. W pierwszej kolejności zaczęła więc kwitnąć literatura. Nie była to jednak byle jaka literatura, ale literatura narodowa, będąca owocem i zwierciadłem duchowego życia tegoż narodu. Tak pisał o tym Wiszniewski: „Dopiero teraz około 1820 roku, kiedy czasy literatury polskiej spełniły się, kiedy obiegła już cały okrąg, w którym nauki i losy ludzkie kołują [...]. Pojawiła się około tego czasu Muza polsko-słowiańska, której rodzinne rysy, i rozlana po twarzy posępność wszystkich zachwyciły. Wieści o tak nadzwyczajnym zjawisku, po wszystkich zakątkach kraju rozbiegły się i powtarzały. Poezja rodzima, od skruszenia posągów Peruna i Światowida, dumnej mądrości łacińskiej pomijana okiem, zwróciła uwagę i tych nawet, którzy dotąd na sam widok rymów i wstrętu i nudności zataić w sobie nie mogli”24. Pierwsze dziesięciolecia XIX wieku to czas odrodzenia literatury narodowej, swoisty jej renesans. Nastąpił spektakularny powrót do jej źródeł, do tego, co rdzennie polskie. Tym skarbcem natomiast, gdzie przechowywano narodowe dziedzictwo, 
był lud, odtrącony, zapomniany, pomijany, zawsze na marginesie życia społecznego, nareszcie (przynajmniej kulturowo) doceniony i dowartościowany: „Dawna literatura polsko-słowiańska, wzgardzona od znamienitszych, jako do pogańskiej przeszłości należąca, schroniła się pod wiejską strzechę i stała się wyłączną własnością ludu wiejskiego, mocniej do dawnych obyczajów i pamiątek przywiązanego"25.

To odrodzenie literatury narodowej, było, zdaniem Wiszniewskiego, wielką nadzieją i znakiem, w kierunku którego Polacy winni podążać. Jednakże dobrze by było, gdyby w ślad za literaturą poszła także filozofia. Naród potrzebuje nie tylko literatury rodzimej, ale także rodzimej filozofii, gdyż - co stosunkowo często podkreśla Wiszniewski - Polacy cierpią na jej brak: „Literatura polska w dziele filozofii nieznaczny dotąd uczyniła postęp” ${ }^{26}$. Na innym miejscu znów stwierdza: „Póki się u nas filozofia, że tak powiem, rodzima, z usposobieniem i kulturą umysłów zgodna, do naszych umysłowych i moralnych potrzeb stosowna nie zjawi, $[\ldots]$ nie rozwiniemy nigdy właściwego nam i bardzo różnego od innych charakteru umysłowego i nigdy się w literaturze do oryginalności podnieść nie zdołamy"27. Polacy potrzebują filozofii oryginalnej, dopasowanej do ich ducha i kondycji umysłowej. Dopóki takiej nie stworzą, będą skazani na ciągłe bycie „w tyle" za innymi narodami, na powielanie obcych idei i wzorów. A postawa taka, ciągłe tkwienie $\mathrm{w}$ „niedołężności i wiecznego umysłu niemowlęctwie”, jest wyrazem zależności znamionującej niedojrzałość. Tylko wówczas, gdy uda nam się stworzyć własną filozofię, staniemy się dojrzałym, świadomym siebie narodem. Dotychczas problemem Polaków było bowiem kopiowanie obcych wzorów i uleganie zagranicznym wpływom. Ta tendencja to wynik dziejów narodowych, wiążących się z kształtowaniem życia umysłowego i intelektualnego w Polsce. Prześledzenie tej historii było ważnym wkładem Wiszniewskiego do tworzącej się wówczas historiografii naukowej

25 M. Wiszniewski, Historia literatury polskiej, t. 1, dz. cyt., s. 182.

26 M. Wiszniewski, Uwagi nad filozofowaniem, cz. 2, „Przyjaciel Ludu” 5 (1839) nr 33, s. 259.

27 M. Wiszniewski, Wykład wstępny, w: M. Wiszniewski, Bacona metoda tłumaczenia natury i inne pisma filozoficzne, Warszawa 1976, s. 66. 
i miało związek także z jego filozofią dziejów. Wytłumaczenie obecnego stanu, cofając się do minionych wieków, pozwoli, zdaniem tegoż filozofa, lepiej zrozumieć przyczyny owego "naśladownictwa” i zapobiegnie powielaniu podobnych błędów w przyszłości.

Historię kształtowania się umysłowości polskiej Wiszniewski zamyka $\mathrm{w}$ dziewięciu epokach ${ }^{28}$, z których ostatnia kończy się na 1840 roku, czyli dacie wydania pierwszego tomu Historii literatury polskiej. Wyodrębnienia konkretnych epok dokonuje on poprzez określenie charakterystycznej cechy, myśli przewodniej: „Każda z nich - pisze nasz Autor - nie jest określoną liczba dowolną, ale obejmuje pewną literatury chwilę, jest oznaczona i napiętnowana myślą, która w niej mocno przebija się, i całe jej życie duchowe przejmuje" ${ }^{29}$. Z tych dziewięciu epok (ich omawianie przekracza ramy tego artykułu) najważniejsze, najbardziej znaczące dla polskiej literatury i filozofii są pierwsze trzy, ponieważ to one nadały kształt ich dalszym losom. Pierwsza epoka są to czasy przedchrześcijańske. Cechuje się ona jednością języka, religii i literatury ${ }^{30}$. Każdy wytwór, przejaw życia duchowego był wówczas ściśle złączony z życiem narodu. Kolejne dwie epoki, obejmujące czasy od zaprowadzenia religii chrześcijańskiej po założenie Akademii Krakowskiej i jej rozkwit w wieku $\mathrm{XV}$ wieku, omawiany tu myśliciel postrzega jako niezbyt szczęśliwe dla kultury rodzimej. Pomimo rozwoju życia intelektualnego, zostało ono zdominowane przez wpływy zachodnie, którym, z różnym rozłożeniem akcentów, ulegało przez kolejne kilka wieków, aż do drugiej i trzeciej dekady wieku XIX. Wówczas to dopiero „literatura polska przez łacińską i francuską w błędnik zawiedziona, [...] obca narodowi, rzuciła na koniec grecką i rzymską przeszłość, poczęła się przeglądać w czasach słowiańskich, chrześcijańskich wiekach i wróciła na łono natury i własnego kraju z radością podróżnego, który z nadmorskich stron do rodzinnej

28 Zob. M. Wiszniewski, Historia literatury polskiej, t. 1, dz. cyt., s. 21-39.

29 M. Wiszniewski, Historia literatury polskiej, t. 1, dz. cyt., s. 21.

30 „Literatura” dla Wiszniewskiego ma dosyć szerokie znaczenie. Nie ogranicza się jedynie do tego, co zostało utrwalone pismem, lecz jest to każdy wyraz życia duchowego i umysłowego, np. przekazywanego drogą tradycji ustnej. 
powrócił strzechy"31. Wtedy więc zaczęła się rozwijać, wróciwszy do czasów, w których stanowiła jedność z życiem i duchem narodu. Przez te dziewięć wieków tym, co ocalało, był polski język, a jedynie literatura i filozofia uległy wpływowi obcych, zwłaszcza łacińskich wzorców, wstrzymując postęp i rozwój rodzimych ${ }^{32}$.

Ten rys historyczny w dziedzinie rozwoju polskiej umysłowości pokazuje, zdaniem Wiszniewskiego, jak dzieje naszego narodu, już u jego początków, naznaczone były obcymi wpływami i jak się od nich uzależniliśmy. To, co rodzime, zawsze wydawało się gorsze, a wzorów i kanonów do naśladowania szukano w tym, co zagraniczne. W Polsce rozwijał się nie „duch narodowy”, ale „duch naśladownictwa”. Stąd radzi Wiszniewski zerwać z imitowaniem i kopiowaniem innych. Dopóki Polacy tego nie uczynią, dopóty będą tkwić w swojej niedojrzałości. Rozwój myśli narodowej jest bowiem analogiczny do rozwoju kultury umysłowej pojedynczego człowieka. Proces uczenia się jednostki można łatwo przetransponować na proces uczenia się całego narodu. Do pewnego momentu może on postępować drogą nauki na zasadzie przyswajania już gotowej wiedzy, jest to naturalny proces i nie ma w tym nic niestosownego. Niemniej, celem nauki nie jest tylko wyuczenie się tego, co już powiedziano, napisano czy zrobiono, ale wypracowanie w sobie zdolności do krytycznego myślenia, przeprowadzenia nowych obserwacji, odkryć, wyprowadzania wniosków oraz przetwarzania nabytej wiedzy, tak by służyła ona określonym celom. Naśladowanie, jak już wspomniano, jest czymś naturalnym i także potrzebnym. Jednakże jest oznaką wieku dziecięcego; jest istotnym elementem w procesie kształcenia i nabywania nowych umiejętności, ale nie ich ostatecznym celem ${ }^{33}$.

Tak samo więc jak z kształtowaniem samodzielnego, świadomego siebie i myślącego człowieka, tak ma się i z formowaniem tego podmiotu, jakim jest naród: „Nie przeczę - konstatuje Wiszniewski - że wszystkie

33 Zob. M. Wiszniewski, Bacona metoda tłumaczenia natury, w: M. Wiszniewski, Bacona metoda tlumaczenia natury..., dz. cyt., s. 4-8. 
narody młodsze albo spóźnione w cywilizacji naśladują starszych; jest to naturalny bieg rzeczy. Grecy nawet, z wrodzonego dowcipu i pojętności tak słynni, wiele od innych narodów się nauczyli, lecz ani w literaturze, ani w kunsztach nie widać u nich naśladowania. Literatura ich jest oryginalna [...]. Idąc za własnym natchnieniem, zamiast piramid wznieśli świątynię Minerwy; a zamiast sfinksów, zostawili Appolina belwederskiego i Laokoona" ${ }^{34}$. Niestety Polacy nie są w tym podobni do Greków. Trudno jest im przejść od naśladowania do wypracowania własnej oryginalności, do pójścia za własnym geniuszem narodowym: „Postępując ciągle ubitą koleją, nie umiemy władać umysłem i używać własnych zdolności. Stąd siła imaginacji i siła wynalazkowi rozumu nieużywaniem słabnieje, i podobnie jak lewa ręka, bywa niemal bezwładna. Umysł tylko łatwiejsze odbywając działanie, tylko do wyrozumienia cudzych myśli używany, sił swoich rozwinąć nie może. Pełzając ciągle po cudzych śladach, zacieramy piętno, czyli charakter naszego umysłu, bo rzadko, kto ucząc się długo od drugich, wrodzone i osobiste właściwości rozumu i świeżą barwę umysłu swego ochronić potrafi”35. W innym miejscu znów pisze: „W rychlejszych wiekach naśladowano Arystotelesa i cudzoziemskich filozofów scholastycznych. W czasach zaś najnowszych tłumaczono lub naśladowano Anglików, Francuzów i Niemców; [...] chwyciliśmy się naśladowania współczesnych nam cudzoziemców i krom najlepszej chęci, hołdowaliśmy obcym zasadom i przepisom, nie doświadczając sił własnych, które by samodzielności ducha dojrzalszym były owocem" ${ }^{36}$.

Kondycja myśli polskiej, zdaniem Wiszniewskiego nie przedstawiała się najlepiej. Dziewięć wieków historii Polski to w większości czas biernej recepcji obcych wzorów, zachwycania się nimi, powielania, bez przykładania większej wagi do rozwijania własnych koncepcji filozoficznych, naznaczonych charakterem narodowym i dopasowanym do jego potrzeb, zgodnych $z$ duchem narodu i go kształtującym. Ponadto filozofia

M. Wiszniewski, Bacona metoda tłumaczenia natury, dz. cyt., s. 7.

M. Wiszniewski, Bacona metoda tłumaczenia natury, dz. cyt., s. 8.

M. Wiszniewski, Uwagi nad filozofowaniem, cz. 2., dz. cyt., s. 259. 
nie ma być „małpowaniem przywiezionych z zagranicy opinii, lecz życiem wewnętrznym duszy" ${ }^{37}$, a ciągłe "naśladowanie lub przerabianie cudzoziemskich systematów filozofii nie może się do wzrostu i postępów jej przyczynić”38. Gdyby - dowodzi Wiszniewski - Anglicy tłumaczyli lub wykładali Wolfa, nie byłoby Hume’a, Hutchesona czy Reida, którzy stali się twórcami nowych koncepcji filozoficznych, założycielami szkół filozoficznych, oddziaływających nie tylko poza granice kraju, ale w sposób szczególny wpływających na swój naród i go formujących ${ }^{39}$. Polacy nie wydali z siebie aż tak znakomitych umysłów.

Według Wiszniewskiego jedynymi Polakami, którzy „za własnym poszli popędem, zachowując ducha prawdziwej Polszczyzny"40, są bracia Śniadeccy. W tym kontekście przywołuje dzieło Jędrzeja Śniadeckiego o jestestwach organicznych, którym zjednał sobie sławę europejską i które zostało przetłumaczone na język francuski i niemiecki. Zdaniem Wiszniewskiego w pierwszym tomie wspomnianego dzieła daje ów polski uczony dowody głębi swych intuicji i myśli filozoficznych. Do tego tok jego rozumowania uważa za jasny, zrozumiały, gruntowny, prezentujący styl filozoficzny, który nie ma dla siebie „wzoru i przygotowania w dziejach ojczystych" ${ }^{41}$. Podobnie Wiszniewski wypowiada się o drugim z braci, Janie Śniadeckim, który „[...] w żywotach stał się narodu polskiego pisarzem klasycznym, w filozofii zaś okazał stanowisko Polakom, na jakiem właściwiej i dogodniej filozoficznym badaniom poświęcić się można"42. Sposób filozofowania obu braci charakteryzuje się więc swobodą, lekkością i przyjemnością, co odpowiada charakterowi Polaków, zgadzając się z naturą języka i stając się tym samym nieocenionym skarbem i wzorem ${ }^{43}$. Spośród współczesnych sobie Wiszniewski dowartościowuje jeszcze Słowackiego i styl dokonanego przez Jana Znoska 
przekładu Logiki Condillaca. Krytykował jednak rozprawy Chłędowskiego, Kamieńskiego, Jarońskiego, Szaniawskiego za styl słabo odpowiadający duchowi polskiemu ${ }^{44}$. To wszystko skłoniło więc i zainspirowało Wiszniewskiego do sformułowania postulatu potrzeby pracy nad własną filozofią rodzimą, narodową, która mogłaby być czynnikiem wyróżniającym nas spośród filozofii europejskich i „ich oczy na nas zwracała”. Byłoby to także wniesieniem jakiegoś bogactwa nie tylko w kulturę i rozwój swojego narodu, ale także we wspólne dziedzictwo europejskie. Konieczne jest zatem, zdaniem Wiszniewskiego, wyzbycie się „naśladownictwa" i mądre, twórcze korzystanie $\mathrm{z}$ dorobku innych narodowości, byśmy „[... z z filozofów cudzoziemskich, do pszczółki podobni, słodyczy tylko starali się wyciągać, zostawiając truciznę nietkniętą" ${ }^{45}$. Wówczas Polacy mogliby odznaczyć się na filozoficznej arenie międzynarodowej oryginalnością idei, nacechowaną własnym i niepowtarzalnym sposobem filozofowania. Jest to tym bardziej konieczne, że zważywszy na sytuację polityczną i ekonomiczną oraz pragnienie odzyskania utraconej niepodległości, Polacy potrzebują takiej filozofii, która będzie mądrością praktyczną, która by „kraj do podniesienia przyczyniła” ${ }^{4}$.

\section{Podsumowanie}

Każda epoka historyczna ma swoją specyfikę, coś, co wyróżnia ją spośród wszystkich innych. Wiek XIX był wiekiem, w którym wśród ludów, zwłaszcza europejskich, coraz bardziej zaczęła wzrastać „świadomość narodowa". To poczucie przynależności do określonego narodu szczególnie żywe stało się wśród pozbawionych swojego państwa Polaków. Wraz $\mathrm{z}$ tęsknotą za tym, co utracone, pogłębiało się $\mathrm{w}$ nich pragnienie odzyskania niepodległości. W realizacji tego pragnienia służyć miała zarówno literatura, jak i filozofia, nie tylko tworzona ku „pokrzepieniu serc”, ale nastawiona na konkretne cele społeczne i polityczne, spełniająca pewną

Zob. M. Wiszniewski, Uwagi nad filozofowaniem, cz. 2, dz. cyt., s. 259.

M. Wiszniewski, Uwagi nad filozofowaniem, cz. 2, dz. cyt., s. 259.

M. Wiszniewski, Wykład wstępny, dz. cyt., s. 671. 
funkcję ideową. Miała to być filozofia narodowa. Do jej tworzenia i propagowania zabrały się największe polskie umysły tamtych czasów (Trentowski, Cieszkowski, Libelt, Kamieński, Dembowski). Wszyscy oni znali filozofię niemiecką (Libelt i Kremer studiowali u Hegla), która w ich poglądach odgrywała rolę inspirującego czynnika. Nie tyle przenosili ją na grunt polski, ile raczej podążając za jej duchem, podjęli się ambitnego kontynuowania idei w niej zawartych, tworząc własne systemy. Tym sposobem filozofia narodowa $\mathrm{w}$ powszechnej świadomości zrosła się $\mathrm{z}$ idealizmem, a także z poglądami o dziejowym posłannictwie naszego narodu, reprezentowanym przez niektórych z jej głównych przedstawicieli. Z tego powodu pojęcie "filozofia narodowa” zaczęło być traktowane jako synonim polskiego romantyzmu ${ }^{47}$. Jednakże jest to tylko część prawdy, ponieważ nie wszyscy myśliciele i filozofowie tamtych czasów byli „wyznawcami” tego nurtu, o proweniencji niemieckiej. Do tego „nieromantycznego" grona należał właśnie Wiszniewski.

Od romantyków oddzielał krakowskiego myśliciela stosunek do filozofii idealistycznej. Jednakże tym, co niewątpliwie go z nimi łączyło, było poczucie potrzeby stworzenia takiej filozofii, która mogłaby stać się narzędziem przeobrażenia świadomości narodowej, walki o niepodległość czy praktyki społecznej. Takiej filozofii, która nie tylko oddziaływałaby na naród, ale z niego wypływała - zgodnej z polskim duchem i usposobieniem. Tego typu filozofii, zdaniem Wiszniewskiego, Polacy jeszcze nie stworzyli, gdyż w swojej przeszłości ulegali obcym, zachodnim prądom ideowym, tylko je naśladując i powielając. Filozofia uprawiana przez polskich filozofów nie odznaczała się więc narodowym charakterem, przez co także sama nie była $\mathrm{w}$ stanie wnieść niczego nowego w myśl europejską czy światową. Potrzebą Polaków było według Wiszniewskiego posiadanie przez nich własnej, oryginalnej filozofii, zawierającej w sobie bogactwo całego ich kulturowego, narodowego, słowiańskiego dziedzictwa. Cechy wyróżniające Polaków na tle innych nacji powinny znajdować wyraz w sposobie ich filozofowania.

47 Por. J. R. Błachnio, Idealizm niemiecki i filozofia narodowa w polskiej myśli chrześcijańskiej lat 1831-1863, Bydgoszcz 1994, s. 55. 
W postawie Wiszniewskiego, analizującego kondycję polskiej myśli, zdaje się dominować koncentracja na stylu uprawiania filozofii. Mało zważa na zawartość ideową, przedmiot czy zagadnienia podejmowane przez polskich myślicieli, na to, co ich szczególnie zajmowało, a co być może wypływało $\mathrm{z}$ ich narodowego usposobienia, jak choćby tak często podejmowana idea wolności. Być może, w tym kontekście, dla Wiszniewskiego nie był ważny przedmiot filozofii, ponieważ to on nadaje jej znamię uniwersalności, a interesował go tylko sposób, w jaki się ją uprawia, nadający jej cechy partykularne, czyniące ją narodową. Jak pogodzić uniwersalizm filozofii z jej narodowym charakterem? Jak realizować uniwersalistyczne dążenia filozofii bez niweczenia narodowych kultur i ich odrębności? Jaką rolę w filozofii odgrywa język? Koncepcja filozofii narodowej Wiszniewskiego byłaby niepełna bez odpowiedzi na te wyżej postawione pytania. Oprócz postulowania potrzeby stworzenia polskiej filozofii narodowej, Wiszniewski miał także konkretną wizję, jak taka filozofia miałaby wyglądać i jakim językiem powinna się posługiwać. Dopełnienie obrazu tejże koncepcji filozofii narodowej Wiszniewskiego wraz z próbą odpowiedzi na pytanie o jej prepozytywistyczny charakter zostanie podjęte $\mathrm{w}$ drugiej części artykułu.

\section{Bibliografia}

Błachnio J. R., Idealizm niemiecki i filozofia narodowa w polskiej myśli chrześcijańskiej lat 1831-1863, Bydgoszcz 1994.

Garfein-Garski S., Zagadnienie polskiej filozofii narodowej, w: Polska filozofia narodowa, red. M. Straszewski, Kraków 1921, s. 5-29.

Halpern I., Jan Śniadecki, w: Polska filozofia narodowa, red. M. Straszewski, Kraków 1921, s. 33-78.

Harassek S., Prolegomena do filozofii narodowej Trentowskiego, „Kwartalnik Filozoficzny" 11 (1933), s. 283-331.

Herder J. G., Myśli o filozofii dziejów, t. 1, tłum. J. Gałecki, Warszawa 1962. Herder J. G., Myśli o filozofii dziejów, t. 2, tłum. J. Gałecki, Warszawa 1962. Jaroński F., Jakiej filozofii Polacy potrzebuja, w: Jakiej filozofii Polacy potrzebują, red.

W. Tatarkiewicz, Warszawa 1970. 
Korbut G., Michał Wiszniewski i spuścizna po nim, Warszawa 1901.

Kozłowski R., Koncepcja „filozofii narodowej” Liberta i Trentowskiego, „Archiwum Historii Filozofii i Myśli Społecznej” 16 (1970), s. 31-53.

Skarga B., Narodziny pozytywizmu polskiego 1831-1864, Warszawa 2013.

Skoczyński J., Woleński J., Historia filozofii polskiej, Kraków 2010.

Struve H., Historia filozofii w Polsce na tle ogólnego rozwoju życia umysłowego, Warszawa 1900.

Szaniawski J. K., Rady przyjacielskie młodemu czcicielowi nauk i filozofi, pragnacemu znaleźć pewniejsza drogę do prawdziwego i wyższego oświecenia, Warszawa 1805.

Szymaniec P., Pojęcie narodu w filozofii dziejów Johanna Gottfrieda Herdera, „Wrocławskie Studia Erazmiańskie” 1 (2008), s. 18-36.

Walicki A., Idea narodu w polskiej myśli oświeceniowej, „Archiwum Historii Filozofii i Myśli Społecznej" 26 (1980), s. 35-97.

Walicki A., Zarys dziejów filozofii polskiej (1815-1918), Warszawa 1986.

Wepsięć J., Michał Wiszniewski i jego filozofia na tle empiryzmu z epoki polskiego Oświecenia, „Kwartalnik Filozoficzny” 15 (1938) z. 3, s. 260-277.

Wiszniewski M., Historia literatury polskiej, t. 1, Kraków 1840.

Wiszniewski M., Myśli o ukształceniu samego siebie, Warszawa 1873.

Wiszniewski M., Uwagi nad filozofowaniem, cz. 2, „Przyjaciel Ludu” 5 (1839) nr 33, s. $258-260$.

Wiszniewski M., Wykład wstępny, w: M. Wiszniewski, Bacona metoda tłumaczenia natury i inne pisma filozoficzne, Warszawa 1976, s. 671-683.

Wiśniewski R., Karola Libelta „system umnictwa” jako filozofia narodowa, „Szkice Humanistyczne" 10 (2010) nr 1, s. 61-76.

\section{Abstrakt}

Prepozytywistyczna (?) koncepcja filozofii narodowej Michała Wiszniewskiego. Cz. 1: Źródła i inspiracje

Powstanie i rozwój polskiej filozofii narodowej zazwyczaj kojarzone są z pierwszą połową XIX wieku i myślicielami doby romantyzmu. Jednakże nie wszyscy filozofowie tamtego okresu należeli do wspomnianego nurtu. Niektórzy bardziej zbliżali się w swych poglądach do idei głoszonych przez późniejszych pozytywistów. Do tego grona należał 
Michał Wiszniewski (1797-1865), profesor Uniwersytetu Jagiellońskiego, przedstawiciel krakowskiego ośrodka naukowego, uważany za jednego z głównych prepozytywistów polskich. Również i on wystąpił z projektem filozofii narodowej. W literaturze z zakresu historii filozofii rzadko się o niej wspomina. Wiszniewski nie napisał osobnego dzieła poświęconego w całości temu zagadnieniu. Myśli odnoszące się do koncepcji filozofii narodowej znajdują się w różnych jego pracach. Celem artykułu jest ich wydobycie, uporządkowanie i dostarczenie w miarę całościowego i spójnego obrazu tejże koncepcji. Z tego względu artykuł został podzielony na dwie części. W pierwszej (którą jest obecny artykuł) zostało zaprezentowane historyczno-filozoficzne tło, na którym zrodziła się koncepcja Wiszniewskiego, oraz czynniki, jakie wpłynęły na sformułowanie przez niego postulatu stworzenia polskiej filozofii narodowej. W artykule zwrócono ponadto uwagę na cechy, które łączą koncepcję Wiszniewskiego z romantykami, idealistami i sprawiają, że trudno jednoznacznie zakwalifikować ją jako prepozytywistyczną. Z drugiej zaś strony wykazano, co wyróżniało projekt Wiszniewskiego, pokazując, że filozofia narodowa niekoniecznie musi oznaczać to samo, co filozofia romantyczna o tendencjach mesjanistycznych.

\section{Słowa kluczowe}

Michał Wiszniewski, filozofia narodowa, prepozytywizm, romantyzm, filozofia XIX wieku

\section{Abstract \\ Michał Wiszniewski's concept of national philosophy. Part 1: Sources and inspirations}

Polish national philosophy is usually associated with the phenomena and concepts prevalent in the first half of the 19th century, i.e. in the Romantic era. This philosophy is traditionally linked with the main representatives of Romanticism, although not all Romantic thinkers belonged to this current - there were also philosophers whose views were closer to the ideas propagated later by positivists. This group includes Michał Wiszniewski (1797-1865), a professor at the Jagiellonian University, and a representative of the Krakow's philosophical milieu, who is considered one of the main Polish prepositivists. He also put forward the idea of a national philosophy project, a concept rarely mentioned in the literature on the history of Polish philosophy. Wiszniewski did not 
write a separate work solely dedicated to this issue, but included thoughts related to the concept of national philosophy in his various works. Therefore, the aim of the article is to extract these thoughts from his works, systematise them, and develop a holistic and coherent picture of this concept. It is divided into two parts, and the purpose the first part is to present sources of Wiszniewski's concept, i.e. the historical and philosophical background against which he developed his idea of national philosophy, and to discuss the factors which led him to postulate that it was necessary to create Polish national philosophy. The article indicates the features shared by Wiszniewski's project and the Romantic ideas, which makes it impossible to call it wholly prepositivistc, as well as the features that differentiate these two, which indicates that national philosophy is not the same as Romantic philosophy.

\section{Keywords}

Michał Wiszniewski, national philosophy, prepositivism, romanticism, nineteenth-century philosophy 